\title{
PENERAPAN METODE PEMBELAJARAN ROLE PLAYING DALAM MENINGKATKAN HASIL BELAJAR BAHASA INDONESIA PADA SISWA KELAS IV SD 166325 KOTA TEBING TINGGI
}

\author{
Rismawati \\ Surel: rismawati.spd0606@gmail.com
}

\begin{abstract}
This purposes of this research is to improve learning result on Indonesian Languange subject through role playing method. This classroom action researchconducted by 2 cycles of the four phases: planning, implementation, observation, reflection. The subjects were students fromgrade IV, Elementary School State166325 Tebing Tinggi which amounted to 33 students. This study used a qualitative descriptive analysis technique. The results showed that the use of the role playing method of Indonesian Languange subjects can improve student learning result characterized by increased mastery learning students, namely pre-cycle (66,67\%), the first cycle $(81,81 \%)$, cycle II $(93,93 \%)$ and complete learn the clasical equal to $93,93 \%$.
\end{abstract}

Keywords : Role Playing, Student Learning Outcomes, Indonesian Language

\begin{abstract}
ABSTRAK
Penelitian ini bertujuan untuk meningkatkan hasil belajar siswa mata pelajaran Bahasa Indonesia melaui metode pembelajaran role playing. Penelitian tindakan kelas ini dilaksanakan sebanyak 2 siklus dengan empat tahapan yaitu: perencanaan, pelaksanaan, observasi, refleksi. Subjek penelitian ini adalah siswa kelas IV SD Negeri 166325 Tebing Tinggi sebanyak 33 siswa. Penelitian ini menggunakan teknik analisis dekriptif kualitatif. Hasil penelitian menunjukkan bahwa penggunaan metode role playing mata pelajaran Bahasa Indonesia dapat meningkatkan hasil belajar siswa yang ditandai dengan peningkatan ketuntasan belajar siswa, yaitu prasiklus $(66,67 \%)$, siklus I $(81,81 \%)$, siklus II $(93,93 \%)$ dan dinyatakan berhasil ssecara klasikal 93,93\%.
\end{abstract}

Kata Kunci : Role Playing, Hasil Belajar Siswa, Bahasa Indonesia.

\section{PENDAHULUAN}

Peningkatan mutu pendidikan diarahkan untuk meningkatkan kualitas manusia seutuhnya melalui olah pikir olah hati dan olah rasa agar memiliki daya saing dalam menghadapi tantangan global. Belajar diartikan sebagai proses perubahan tingkah laku pada diri individu berkat adanya interaksi antara individu dengan lingkungannya (Usman, 2000:5).
Guru sebagai pengajar merupakan pencipta kondisi belajar siswa yang didesain secara sengaja, sistematis dan berkesinambungan. Sedangkan siswa sebagai subjek pembelajaran merupakan pihak yang menikmati kondisi belajar yang diciptakan guru pada proses pembelajaran di kelas, keduanya saling, mempengaruhi dan memberi masukan. Oleh karenanya itu kegiatan belajar merupakan aktifitas yang hidup syarat nilai dan 
memiliki tujuan (Fathurrahman, dkk. 2007).

Bahasa sebagai alat komunikasi merupakan sarana yang sangat penting dalam kehidupan anak. Di samping itu, bahasa juga merupakan alat untuk menyatakan pikiran dan perasaan kepada orang lain yang sekaligus berfungsi untuk memahami pikiran dan perasaan orang lain (Syaodih dan Agustin, 2010). Bahasa Indonesia memiliki kedudukan dan fungsi yang sangat penting yakni sebagai bahasa negara dan bahasa nasional. Pembelajaran Bahasa Indonesia khususnya di sekolah dasar bertujuan untuk meningkatkan kemampuan berkomunikasi dalam bahasa Indonesia dengan baik dan benar, baik secara lisan maupun tulisan. Secara umum, tujuan pengajaran bahasa Indonesia di SD adalah siswa memiliki disiplin berpikir dan bahasa pasif dan aktif (berbicara), menyimak dan membaca serta menulis.

Namun kenyataannya dilapangan berdasarkan observasi yang telah dilakukan oleh peneliti menunjukkan hasil belajar siswa kelas IV SD Negeri 166325 Tebing Tinggi masih rendah khususnya dalam keterampilan berbicara.Hal ini terbukti dari rendahnya rata-rata nilai ulangan harian siswa yaitu 68. Dari 33 siswa, hanya 22 siswa yang memenuhi nilai ketuntasan belajar (nilai 70) dan masih terdapat 11 siswa yang tidak memenuhi nilai ketuntasan. Sehingga presentase siswa yang lulus hanya $66,67 \%$ dan masih terdapat $33,33 \%$ siswa yang mendapat nilai dibawah nilai ketuntasan.

Dalam proses pembelajaran Bahasa Indonesia, kegiatan siswa masih kurang diperhatikan, siswa hanya diminta untuk memperhatikan penjelasan guru dan jarang sekali diminta untuk bertanya. Siswa jarang sekali diminta untuk memberikan pertanyaan atau memberikan pendapat terhadap materi pelajaran yang sedang dipelajari. Akibatnya tidak jarang ditemukan siswa yang mengganggu temannya pada saat belajar dan tertidur di dalam kelas.

Salah satu alternatif yang dianggap efektif dan efisien diantaranya adalah dengan melakukan penelitian tindakan kelas metode role playing. Role Playing siswa dapat bertindak dan mengekspresikan perasaan dan pendapat tanpa kekhawatiran mendapat sangsi. Mereka dapat pula mengurangi dan mendiskusikan isuisu yang bersifat manusiawi dan pribadi tanpa ada kecemasan. Bermain peran memungkinkan para siswa mengidentikasikan situasisituasi dunia nyata dan dengan ideide orang lain. Dengan cara ini, anak dilengkapi dengan cara yang aman dan kontrol untuk meneliti dan mempertunjukkan masalah-masalah diantara kelompok/individu (Hamalik, 2003).

Metode role playing disebut juga sosiodrama maupun bermain peran.Metode role playing adalah suatu cara penguasaan bahan-bahan pelajaran melalui pengembangan 
Rismawati: Penerapan Metode Pembelajaran Role Playing...

imajinasi dan penghayatan yang dilakukan siswa dlam memerankannya sebagai tokoh. Permainan ini pada umunya dilakukan lebih dari satu orang, hal ini tergantung kepada yangdiperankan (Komalaris, 2011). Dengan cara belajar mengajar semacam ini, para siswa diberi kesempatan dalam menggambarkan, mengungkapkan, atau mengekspresikan suatu sikap, tingkah laku atau penghayatan sesuatu yang dipikirkan, dirasakan, atau diinginkan seandainya ia menjadi tokoh yang sedang diperankannya itu.

Metode ini, pertama, dibuat berdasarkan asumsi bahwa sangatlah mungkin menciptakan analogi otentik ke dalam suatu situasi permasalahan kehidupan nyata.Kedua, bahwa bermain peran dapat mendorong siswa mengekspresikan perasaannya dan bahkan melepaskan. Ketiga, bahwa proses psikologis melibatkan sikap, nilai, dan keyakinan kita serta mengalahkan pada keasadaran melalui keterlibatan spontan yang disertai analisis (Hamzah, 2007). Melalui bermain peran siswa belajar menggunakan konsep peran, menyadari adanya peran-peran yang berbeda dan memikirkan perilaku dirinya dan perilaku orang lain.

Role playing merupakan suatu cara penguasaan bahan-bahan pelajaran melalui pengembangan imajinasi dan penghayatan dilakukan oleh peserta didik. Pengembangan imajinasi dan penghayatan yang dilakukan oleh pesertadidik dengan memerankan dirinya sendiri sebagai tokoh hidup atau benda matikarena kegiatan memerankan akan membuat peserta didik lebih meresapi perolehannya (Shaleh, 2000).

Bermain peran dalam pembelajaran merupakan usaha untuk memecahkan masalah melalui peragaan serta langkah langkah identifikasi masalah, analisis pemeranan dan diskusi. Untuk kepentingan tersebut sejumlah peserta didik bertindak sebagai pemerandan yang lainnya sebagai pengamat. Seorang pemeranharus mampu menghayati peran yang dimainkannya (Mulyasa, 2013). Melalui peran, peserta didik berinteraksi dengan orang lain yang juga membawakan peran tertentu sesuai dengan tema yang dipilihnya.

Dari uraian di atas dapat disimpulkan bahwa tujuan metode RolePlaying (bermain peran) adalah pembelajaran yang bertujuan untuk memerankan materi ajar yang diharapkan nantinya siswa dapat menerima dan menyerap materi yang diberikan oleh guru. Namun guru harus lebih menguasi langkah pembelajaran. Karena apabila pelaksanaan bermain peran mengalami kegagalan bukan saja dapat memberi kesan kurang baik, tetapi sekaligus tujuan pembelajaran tidak tercapai.

Berdasarkan permasalahan tersebut maka penulis tertarik untuk meneliti penerapan metode ini pada pelajaran Bahasa Indonesia karena siswa dapat terlibat secara aktif 
dalam kegiatan proses pembelajaran dengan mengekspresikan perasaan dan pendapat tanpa mengkhawatirkan mendapatkan sangsi. Bermain peran memungkinkan para siswa mengidentifikasi situasi-situasi dalam dunia nyata dan dengan ideide orang lain.

Tujuan dari penelitian ini adalah untuk meningkatkan hasil belajar PKn siswa kelas IV SD Negeri 166325 kota Tebing Tinggi melalui metode pembelajaran role playing.

\section{METODE PENELITIAN}

Penelitian ini diawali dengan pengajuan judul tentang penelitian yang akan dilaksanakan. Subyek penelitian adalah siswa kelas IV SD Negeri 166325 Tebing Tinggi dengan jumlah siswa sebanyak 33 orang dengan 15 orang laki-laki dan 18 orang perempuan. Sumber data yang digunakan adalah siswa dan teman sejawat. Pada Penelitian tindakan kelas data yang dikumpulkan dapat berbentuk kuantitatif maupun kualitatif.

Penelitian tindakan kelas tidak menggunakan uji statistik, tetapi dengan deskriptif. Data kuantitatif yang berupa nilai dianalisis dengan menggunakan analisis deskriptif komparatif yaiu membandingkan nilai tes kondisi awal, nilai tes setelah siklus Idan siklus II yaitu nilai dari hasil ulangan harian siswa kelas IV SD Negeri 166325 pada siklus Idan siklus II. Komponen pengajaran metode role playing yang sangat data kualitatif yang berupa observasi kegiatan guru, dan sisa serta data kuantitatif yang berupa nilai hasil ulangan harian siswa kelas IV. Model penelitian tindakan kelas yang digunakan peneliti adalah system spiral refleksi diri yang dikembangkan oleh Kemmis dan Taggart (1990: 11) yang dimulai dengan perencanaan, tindakan, pengamatan, dan refleksi.

\section{Siklus I}

Guru melakukan pembelajaran di dalam kelas dengan menggunakan panduanperencanaan yang telah dibuat. Sebelumnya guru memberikan pretes untuk mengetahui penguasaan konsep sebelum mengikuti mata pelajaran. Penerapan metode role playing dilakukan dengan menugaskan kepada masing-masing kelompok untuk mendiskusikan tema yang ditetapkan. Setelah para peserta didik berdiskusi, kemudian pendidik meminta setiap kelompok untuk memerankan dramanya.Pada saat kegiatan pembelajaran berlangsung guru sebagai peneliti dibantu oleh para observer lainnya untuk melakukan pengamatan, pendokumentasian, selain itu peneliti bertindak sebagai fasilitator, motivator dan sekaligus sebagai pengamat.

\section{Siklus II}

Siklus II dilaksanakan sama dengan siklus I hanya saja hal-hal yang perlu diperbaiki pada siklus I dilakukan pada siklus II. Pada Siklus 
Rismawati: Penerapan Metode Pembelajaran Role Playing...

kedua ini juga, suasana pembelajaran masing-masing kelompok di lingkungan sekolah dikondisikan agar tidak terlalu formal, maksudnya siswa bebas mengemukakan pendapatnya tentang materi ajar sesuai dengan kompetensi dasar yang ingin dicapai.

Pengamatan dilakukan peneliti sendiri dan dibantu oleh pengamat dan mencatat proses penerapan teknik pengajaran kolaborasi.

Peneliti mengkaji, melihat dan mempertimbangkan hasil atau dampak dari tindakan yang dilakukan berdasarkan lembar pengamatan yang diisi oleh pengamat.Tahapan ini dilakukan secara berkesimbungan sehingga ditemukan hasil yang optimal Kegiatan pada tahap refleksi meliputi kegiatan menganalisis, memahami dan membuat kesimpulan berdasarkan hasil observasi setiap siklus.Menemukan kelebihan dan kelemahan tindakan perbaikan pembelajaran. Hasil analisis data yang dilaksanakan pada tahap ini akan dipergunakan untuk menemukan kelebihan dan kelemahan diri dalam merancang dan melakukan tindakan sebagai acuan.

\section{HASIL PENELITIAN DAN PEMBAHASAN}

kelas menunjukkan bahwa pengamatan yang dilakukan oleh peneliti kepada siswa melalui penerapan metode role playing pada mata pelajaran Bahasa
Indonesia.Kegiatan penelitian diawali dengan pemberian pretets dilakukan untuk mengetahui penguasaan konsep dan mengetahui kemampun awal peserta didik sebelum mengikuti mata pelajaran. Setelah pre test diberikan, pada kelassiswa diberi tahu bahwa pada pertemuan berikutnya pembelajaran IPS akan menggunakan metode Role Playing. Selanjutnya guru menunjuk beberapa kelompok yang akan memerankan tokoh pada perlakuan pertama.

Menerapkan metode role playing pada kelas eksperimen dan menjaskan garis besar menganai metode tersebut dan menerapkan metode konvensional atau metode yang biasa digunakan pendidik SD Negeri 166325 Tebing Tinggi dalam mengajar di kelas. Hasil penelitian dari praksiklus, siklus I dan II dapat dilihat pada Tabel 1 yaitu sebagai berikut:

\section{Tabel 1. Peningkatan Hasil Belajar Siswa Siklus I dan II}

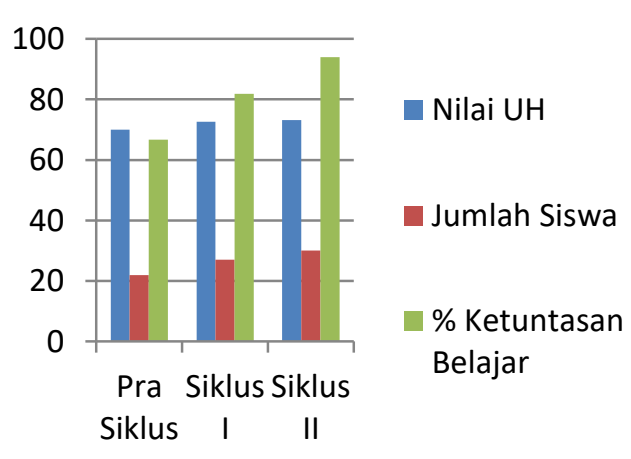

Berdasarkan pengamatan peneliti dari tindakan pra siklus, siklus I dan siklus II pada Tabel 1 
terjadi peningkatan hasil belajar pada jumlah siswa dan persen ketuntasan belajar secara klasikal. Hal ini dapat dilihat dengan peningkatan jumlah siswa dari 22 siswa yang tuntas belajar pada pra siklus menjadi 27 siswa yang tuntas belajar melalui metode pembelajaran role playing.

\begin{tabular}{llr} 
& Selama & siswa memainkan \\
peran guru mengawasi dan & \multicolumn{1}{c}{ man } \\
memberikan & dorongan serta
\end{tabular}
motivasi. Setelah permainan selesai diadakan diskusi mengenai jalannya Role Playing dilanjutkan dengan pembahasan materi yang telah dimainkan.Kemudian guru memberikan tindak lanjut berupa evaluasi individu. Setelah evaluasi selesai, siswa dengan bimbingan guru menyimpulkan materi yang telah dipelajari. Di akhir pembelajaran, guru membagikan soal untuk dijawab oleh siswa.

Observasi dilaksanakan saat proses pembelajaran Bahasa Indonesia berlangsung. Observasi sikap siswa dilaksanakan pada kelas eksperimen dan kelas kontrol untuk mengetahui sikap siswa selama proses pembelajaran berlangsung. Observasi dilakukan oleh pengamat yang merupakan rekan sejawat peneliti. Observasi terdiri dari 10 poin yang berkaitan dengan sikap siswa pada saat proses pembelajaran..

Hasil ulangan siswa pada pelajaran Bahasa Indonesia di kelas IV masih kurang memuaskan, yaitu persentase ketuntasan hanya $81,81 \%$ dengan nilai rata-rata72,6, sedangkan
Kriteria Kelulusan Minimal (KKM) yang harus dicapai siswa adalah 70 . Dari 33 orang siswa yang mengikuti ujian pada pelajaran PKn hanya 27 orang siswa atau $15,14 \%$ yang berhasil mendapatkan nilai di atas nilai 70 atau ketuntasan belajar sebesar $81,81 \%$. Sedangkan 6 orang siswa masih mendapat nilai di bawah nilai 70. Hasil tersebut menunjukkan bahwa pada siklus pertama secara klasikal siswa belum tuntas belajar, karena siswa yang memperoleh nilai $\geq 70$ hanya sebesar $81,81 \%$ lebih kecil dari persentase ketuntasan yang dikehendaki yaitu sebesar $85 \%$. Hal ini disebabkan karena siswa masih bingung dalam memahami konsepkonsep materi pembelajaran.Siswa masih terlihat pasif dan malu-malu dalam memainkan peran yang diberikan oleh guru. Oleh karena itu dilanjutkan penelitian siklus kedua untuk meningkatkan hasil belajar siswa.

Pada siklus II, hasil belajar siswa meningkat dari sikus I. Peningkatan tersebut terjadi karena pembelajaran pada siklus I telah diperbaiki dan kemudian diaplikasikan pada siklus II. Pembelajaran pada siklus 2 tetap menggunakan metode pembelajaran role playing dengan persiapan yang lebih baik lagi. Siswa yang mulai tidak canggung dalam bermain peran membuat suasana belajar semakin menyenangkan. Siklus II dilakukan untuk mendukung dan memperkuat hasil belajar pada siklus. Peningkatan hasil belajar siswa pada siklus II terbukti dengan meningkatnya 
persentase ketuntasan belajar dari $81,81 \%$ menjadi $93,93 \%$ atau ada 31 siswa dari 33 siswa yang sudah tuntas belajar pada siklus II dengan nilai rata-rata 73,2. Hasil tersebut menunjukkan bahwa pada siklus kedua secara klasikal siswa sudah tuntas belajar, karena siswa yang memperoleh nilai $\geq 70$ sebesar 93,93\%. Nilai tersebut sudah melebihi dari persentase ketuntasan yang dikehendaki yaitu sebesar $85 \%$.

Pada siklus II, siswa sudah dapat bekerja sama dengan teman sekelompoknya meskipun masih ada siswa yang pasif namun hal ini masih dianggap baik oleh peneliti. Siswa dapat menyelesaikan tugas dengan baik. Ada keberanian siswa untuk dapat menjawab pertanyaan yang diberikan oleh guru. Siswa dapat memahami konsep-konsep materi pembelajaran yaitu dengan mengetahui sistem pemerintahan desa dan kecamatan. Selain itu, siswa memiliki keberanian untuk dapat menjawab pertanyaan yang diberikan oleh guru. Hasil belajar siswa ini digunakan untuk mengetahui sejauh mana pemahaman siswa terhadap materi pembelajaran yang telah disampaikan.Peningkatan ini terjadi selain karena sudah dilakukan perbaikan oleh peneliti dan siswa yang tidak canggung lagi, juga karena materi pemnbelajaran yang sudah mereka pelajari sebelumnya pada siklus I.

Siswa menunjukkan kesungguhan mereka dalam bermain peran karena sebelumnya belum pernah diterapkan metode pembelajaran lain yang mereka anggap menyenangkan dan tidak membosankan. Metode role playing juga mampu menciptakan suasana belajar yang menyenangkan terbukti dengan meningkatnya motivasi belajar siswa yang diamati oleh observer selama kegiatan pembelajaran. Metode pembelajaran role playing yang menggunakan pola permainan dapat meningkatkan motivasi belajar siswa sehingga hasil belajar siswa pun semakin meningkatnya dengan hasil belajar.

\section{Pembahasan}

Metode Role Playing dalam pelaksanaanya dilakukan dengan berperan atau memainkan peranan dalam dramatisasi masalah sosial. Sebagaimana yang disampaikan oleh Shaleh (2000) bahwa role playing merupakan suatu cara penguasaan bahan-bahan pelajaran melalui pengembangan imajinasi dan penghayatan dilakukan oleh peserta didik. Pengembangan imajinasi dan penghayatan yang dilakukan oleh peserta didik dengan memerankan dirinya sendiri sebagai tokoh hidup atau benda mati karena kegiatan memerankan akan membuat peserta didik lebih meresapi perolehannya.

$$
\text { Berdasarkan hasil yang }
$$
didapat dari setiap siklus proses pembelajaran yang optimal, hal ini ditunjukkan dengan meningkatnya penguasaan materi dan hasil belajar siswa. Oleh karena itu dapat disimpulkan bahwa proses pembelajaran dengan penerapan metode role playing sangat sesuai 
dengan mata pelajaran Bahasa Indonesia maka Penelitian Tindakan Kelas (PTK) ini bisa dikatakan berhasil karena hasil peningkatan proses pembelajarannya optimal.

\section{SIMPULAN}

Dari hasil temuan penelitian tentang hasil belajar siswa dengan metode rrole playing pada pelajaran Bahasa Indonesia di kelas IV SD Negeri 166325 Tebing Tinggi berdampak positif dalam meningkatkan hasil belajar siswa. Hal tersebut dapat dilihat dari peningkatan persentase ketuntasan belajar siswa pada pra siklus $(66,67 \%)$, siklus I $(81,81 \%)$ dan siklus II $(93,93 \%)$.

\section{DAFTAR RUJUKAN}

Fathurrahman, P. Dkk. 2007. Strategi Belajar Mengajar. Bandung: Rifaka Aditama.

Hamalik, O. 2003.Proses Belajar Mengajar. Bandung: Bumi Aksara.

Hamzah, U. 2007.Model Pembelajaran, Jakarta: Bumi Aksara.

Komalaris, K. 2011. Pembelajaran Kontekstual Konsep Dan Aplikasi, Bandung: Refika Adimata.

Mulyasa E. 2013. Pengembangan Dan Implementasi Kurikulum. Bandung: PT. Remaja Rosdakarya.

Shaleh, A. R. 2000. Pendidikan Agama dan Keagamaan. Jakarta: PT. Gemawindu Pancaperkasa.
Syaodih, Ernawulan dan Mubiar Agustin. 2010. Bimbingan Konseling Untuk Anak Usia Dini. Jakarta: Universita Terbuka.

Usman, Uzer. 2000. Menjadi Guru Profesional. Bandung: PT. Remaja Rosdakarya. 